DOI:10.24193/tras.57E.9

Published First Online: 06/25/2019

\section{PROBLEMS OF THE FUNCTIONING OF E-ADMINISTRATION IN THE SILESIAN REGION OF POLAND FROM THE PERSPECTIVE OF A PERSON WITH DISABILITIES*}

\section{Radoslaw WOLNIAK \\ Bożena SKOTNICKA-ZASADZIEŃ Michał ZASADZIEŃ}

Abstract

The article presents an analysis of the functioning of e-administration in municipal offices in the Silesian Province in Poland. It was evaluated by handicapped people with various degrees of disability, of different ages and different educational backgrounds. In Poland the disabled, similarly to abled-bodied people, have to take care of various official matters in offices. It is important that all these clients, in particular the handicapped, can arrange things without leaving their home. The following hypothesis has been formulated in the present article: more frequent use of electronic tools for communication with the office leads to increased satisfaction of the disabled client with the functioning of e-administration. Based on the study conducted, the following variables received the highest scores: functioning of an office's website under various browsers (score 4.89); providing a service in a safe way (4.76); polite and friendly attitude of employees towards clients having trouble using the e-office (4.75); employees' assistance for the client in the event he/she makes a mistake when using the e-office (4.75).

The lowest rated issues among the investigated variables include: promptness of employees' response to e-mails (4.29), promptness of e-service provision (3.34), and taking care of official business on the first attempt (4.42).

Keywords: e-administration, development, the disabled persons, Poland, Silesian Province, municipal office.

\section{Radoslaw WOLNIAK}

Associate professor, Faculty of Organization and Management, Silesian Technical University, Gliwice, Poland

Tel.: 0048-322-777.311

E-mail: radek_wol@o2.pl

\section{Bożena SKOTNICKA-ZASADZIEŃ}

Assistant professor, Faculty of Organization and Management, Silesian Technical University, Gliwice, Poland

E-mail: bozena.skotnicka@polsl.pl

\section{Michał ZASADZIEŃ}

Assistant professor, Faculty of Organization and Management, Silesian Technical University, Gliwice, Poland

E-mail: michal.zasadzien@polsı.pl

* Acknowledgement: The analysis in this publication has been made in the course of the research project 'Appointment profile model of factors affecting the level of customer service with a disability in terms of sustainability of public administration on the example of the Silesian Province', UMO-2012/05/B/HS4/01144 university symbol PBU-12/ ROZ3/2013, funded by the National Center for Science in the OPUS. 


\section{Introduction}

In every society there are disabled people who also have to take care of all kinds of administrative businesses in municipal offices. All public institutions, in particular municipal offices, must be adjusted to the needs of the handicapped (Garbat, 2013). An office is a place where very important issues are arranged, such as registration of residence, issuance of identity cards and passports etc., therefore these public institutions should be equipped with different facilities for the disabled so that the latter could access the office in a comfortable way, get around it and take care of all of their matters (Pradela, 2014). Clerks should undertake any necessary measures to ensure that the clients, especially the handicapped, are served at the highest possible level (Bartnicka and Mleczko, 2013).

\section{Types of disability}

Pursuant to the Law included in the Journal of Laws no. 123, item 176 as of 1997, with subsequent changes in 2002, concerning professional and social rehabilitation as well as employment of the disabled, the definition of a disabled person is as follows: 'The disabled are people whose physical, psychological or intellectual condition permanently or periodically hinders, limits or makes impossible the fulfilment of social roles, in particular limiting their abilities to perform professional work'.

Disabled persons very often make use of services provided by public institutions, which include municipal offices. It is important that self-government units are prepared to provide services to the disabled, both the ones visiting the office in person and those using e-administration (Kažemikaitiene and Bilevičiene, 2008). Handicapped persons have different degrees of disability, therefore it is essential to ensure for them the possibility of taking care of their official business in offices (Garbat, 2013). A municipal office that provides high-level services and fulfils its role should become the major goal for the management of every office (Ruso et al., 2013). The quality of services should be controlled and monitored on a regular basis; offices have to pay attention to and promptly eliminate any problems in communication between the client and the clerks (Kasprzyk, 2011). It is important that these organizations immediately react to problematic situations and remove their causes. Municipal offices are institutions which provide services for all citizens; a resident of a given town cannot move to the so-called competitors, therefore in offices, which are monopolists in this situation, the level of provided services should be evaluated on a permanent basis and problems eliminated straight away. The disabled live in every society, constituting a large group of people. The degree of disability is very different. Six types of disabilities can be distinguished (Kasprzyk, 2011):

- Sensory impairment - disorder, damage or lack of sensory functions; such impairments include the blind, the deaf, the aurally impaired, the visually impaired and persons suffering from disorders related to hearing and sight perception).

- Intellectual impairment, which includes mental retardation and senile dementia. 
- Social functioning impairment; this group includes disorders related to neural balance, emotional balance and mental health.

- Communication impairment related to hindered verbal contact; disorders in this group include autism, speech impediments, stammering.

- Motor impairment - people with motor organ dysfunction. It can be inborn or acquired. Cerebral palsy - damage to foetus brain.

- Psycho-physical impairment caused by physical illnesses, such as: neoplasms, brain tumor, diabetes (Frankfort-Nachmias, Nachmias and DeWaard, 2014).

The most frequent causes of disability include inborn defects (for example Down syndrome, genetic diseases). Chronic diseases account for $80 \%$ of all causes of disability; motor disability is most frequently caused by rheumatic diseases and dementia (Pradela and Żabińska, 2015). A large number of handicapped people point to sudden accidents, such as transportation injuries, accidents in a workplace as well as injuries and poisonings as the cause of their condition. All the reasons lead to a sudden loss of mobility, sensory and intellectual capacity. In 1980 World Health Organization presented an International Classification of Impairments, Disabilities and Handicaps (Bickenbach et al., 2012; Bogucki, 2005). According to this division, the concept of disability has been deemed as biological. The process of becoming a disabled person can be related to three dimensions: injury related to a disorder of the structure of organs, mental disorder due to an inborn defect or as a result of a sudden event (Wiliński, 2010; Tỏza, 2013).

Depending on the degree of a person's disability (Table 1), the disabled make use of the services provided by a municipal office in a direct way, visiting the office, or settle administrative matters via the Internet, using the so-called e-administration for this purpose.

\section{Functioning of e-administration in municipal offices}

Development of e-administration in Poland is related to the project 'Strategy for development of information society in Poland until 2013'. This project defined the activities that needed to be undertaken in order to improve the availability and effectiveness of services provided by public administration. One of the major goals of this project was to reduce the internal circulation of paper documents. The second goal was to increase citizens' access to documents in an electronic form. All these activities were an element of a European Commission's concept which assumed that in the years 2011-2015 the functioning of e-administration and application of informative-communication technologies in public services should have been improved (Kasprzyk, 2011; Banasikowska and Stanek, 2012; Izdebski and Kulesza, 2004).

Implementation of e-administration brings benefits for public administration institutions, such as reduced costs involved in the provision of information and services, and increased effectiveness of work performed (Batta, Sethi and Kaur, 2012). Providing online information is cheaper (Banasikowska and Stanek, 2012; Szewczyk, 2007). 


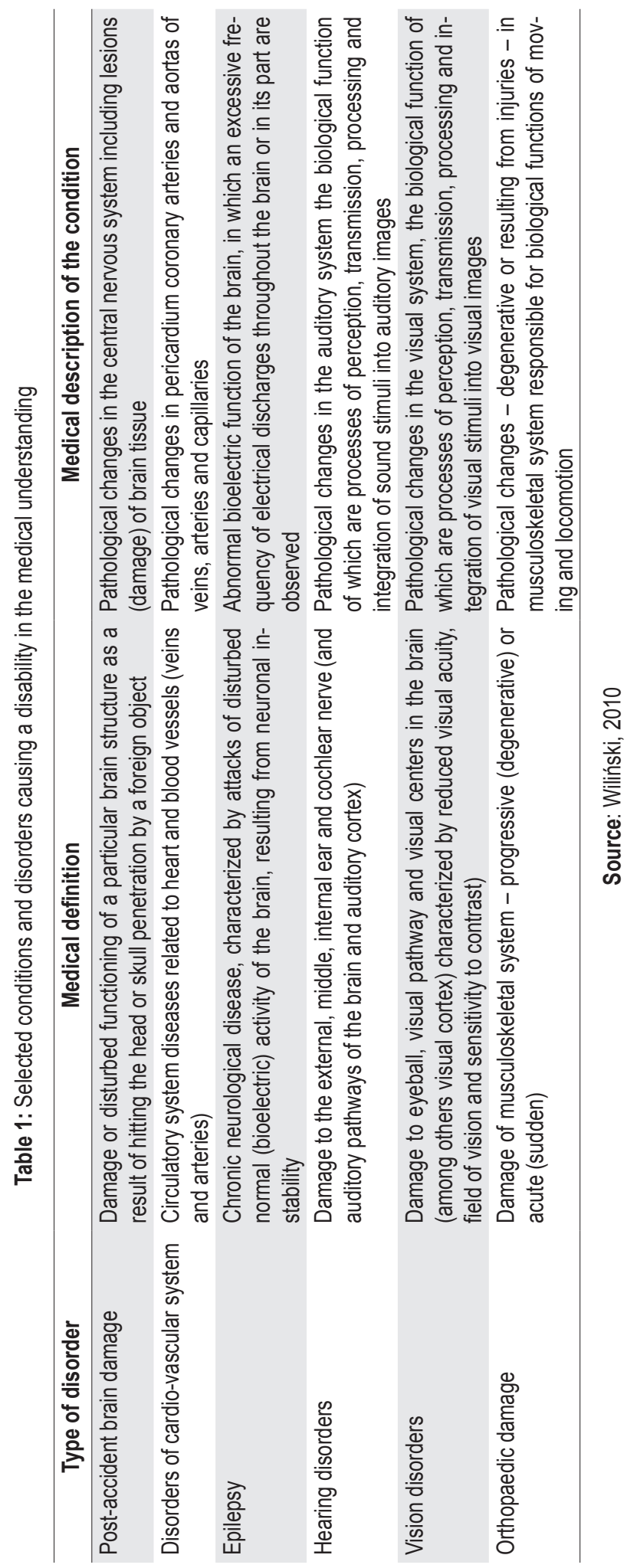


Further benefits include shorter time of service provision thanks to the possibility of completing a form online, a lower number of people visiting offices and, in consequence, smaller queues to desks, reduced expenses and employment, a lower number of complaints, as the majority of forms are completed electronically, reduced quantities of purchased office materials (Omariba Bosire and Okebiro Omari, 2015). Benefits for citizens include: better monitoring of citizen's matters, shorter time for waiting and settling a particular matter. Apart from benefits resulting from the implementation of e-administration, municipal offices also have to bear the costs of this process (Holliday and Yep, 2005). Major expenses include: purchase of computer hardware, computer service, purchase of software, system modernization, website updating, training of staff and visitors (Vrabie, 2015) as well as the implementation of effective forms of data security (García et al., 2015), marketing and advertising (Strejcek and Theil, 2002). Table 2 presents the benefits and costs of e-administration implementation.

Table 2: Benefits and costs of e-administration implementation

\begin{tabular}{|c|c|c|}
\hline Effects & Public administration & Clients \\
\hline \multirow{4}{*}{ Financial } & \multicolumn{2}{|c|}{ Costs } \\
\hline & $\begin{array}{l}\text { - } \text { purchase of equipment and infrastructure; } \\
\text { - } \text { change of employment structure; } \\
\text { - } \text { costs of outsourced services; } \\
\text { - } \text { operational costs; } \\
\text { - } \text { maintenance costs; } \\
\text { - } \text { marketing and advertising; } \\
\text { - } \quad \text { security system. }\end{array}$ & - real cost of Internet access; \\
\hline & \multicolumn{2}{|c|}{ Benefits } \\
\hline & $\begin{array}{l}\text { Savings related to: } \\
\text { - } \text { delivery of services; } \\
\text { - } \text { staff reduction; } \\
\text { - } \text { reduction of office area, office materials; } \\
\text { - } \quad \text { reduction of low-skilled jobs. }\end{array}$ & $\begin{array}{l}\text { - savings related to the preparation and } \\
\text { shipment of documents in a paper form, } \\
\text { arriving in the office, cheaper services; }\end{array}$ \\
\hline & \multicolumn{2}{|c|}{ Costs } \\
\hline Non-financial & $\begin{array}{l}\text { - } \quad \text { streamlined circulation of documents; } \\
\text { - } \quad \text { shortened time of handling official business; } \\
\text { - } \quad \text { effective communication with citizens; } \\
\text { - } \quad \text { streamlined organizational structure; } \\
\text { - } \text { reduced congestion of facilities; } \\
\text { - } \quad \text { reduced number of complaints; } \\
\text { - } \quad \text { faster collection of public amounts due; } \\
\text { - } \quad \text { creating new services; } \\
\text { - } \text { easier control; } \\
\text { - } \quad \text { reduced level of bureaucracy; } \\
\text { - } \text { greater transparency of office functioning. }\end{array}$ & $\begin{array}{l}\text { - time savings related to access to the of- } \\
\text { fice; } \\
\text { - } \text { shorter time of handling official business; } \\
\text { - } \text { greater independence; } \\
\text { - better access to matters monitoring; } \\
\text { - } \text { comfortable access to services; } \\
\text { - better access to a larger amount of infor- } \\
\text { mation; } \\
\text { - integrated process of application and set- } \\
\quad \text { tling matters. }\end{array}$ \\
\hline
\end{tabular}

Source: Brodnicki, Kubiszewska and Tymoszuk, 2012

Functioning of e-administration is very important - it considerably improves the quality of citizens' living, and in the case of the disabled, it brings even greater tan- 
gible benefits. Summing up, it can be stated that universal advantages and benefits of using e-administration in public services include comfort, reduced time and geographical barriers, financial savings and a wider range of services offered (Teicher, Hughes and Dow, 2002; Dečman, Stare and Klun, 2010). In European Union countries citizens' and economic units' service was introduced long time ago. In the countries where such a system is functioning there are notable savings in public administration (Ndou, 2004; Betchoo, 2016a). The quality of public office customer service is also evaluated better (Brinkerhoff and Brinkerhoff, 2002).

\section{E-administration in Poland}

E-administration has been implemented in nearly all municipal offices in the Silesian Province. Implementation of this kind of e-administration service, e-government, considerably improves the quality of living of residents who use services provided by municipal offices (Betchoo, 2016b). This is particularly important for the handicapped, irrespective of the degree of their disability. These people prefer to settle all kinds of official matters without leaving their homes, which is confirmed by survey studies. The advent of the Internet and development of communication-related technology allowed for changing the broadly understood administration from 'paper' to electronic work, which is much more comfortable and faster. Most countries in the European Union, including Poland, contact each other about official matters electronically. In Poland the situation is different, but in the majority of provinces it is average or good (Banasikowska and Stanek, 2012; Salvatore, 1998).

Public administration in Poland is the state's plethora of instruments, consisting of relevant structures which have been created to perform particular tasks of the state. Major tasks of such bodies include undertaking actions in the following areas of life: education, culture, trade, residential housing, railway and urban transport as well as environmental protection. Public administration in Poland is divided into state and self-government administration (Banasikowska, 2009; Wolniak and Skotnicka-Zasadzień, 2010).

According to the European Commission's definition, e-administration is the use of information and communication technologies in public administration, which is closely related to the need of introducing necessary organizational changes, including the improvement of the quality of provided services. In Poland the difference between traditional administration and e-administration is connected with a change of role, namely, traditional administration was a body having power over citizens, whereas e-administration is an institution providing all kinds of administrative services via the Internet.

Any e-administration activities should be undertaken in line with the regulations contained in the Administrative Procedure Code (the Journal of Laws no. 30 item 168 as of July 14, 1983). Implementation of e-administration throughout the country will have to be legally regulated. Until present the issues of electronic signature and elec- 
tronic data archiving have been legally regulated (Banasikowska and Banasikowski, 2008; Liu and Yuan, 2015).

Apart from legal regulations related to the functioning of e-administration, it is very important to create an appropriate platform for carrying out public administration tasks. The Internet has become a natural channel for delivering e-government services. The major services provided by e-administration include:

- in the case of private persons: health care service, social benefits, building permits, police - handling reported crimes and car registration, identity documents, employment agency, information about a change of residence, public libraries, civil registry, personal income tax, registration at universities; and

- in the case of enterprises: obligatory social insurance, corporate tax, VAT, registration of enterprises, registration in Central Statistical Office, customs declaration, environmental agency permit, public orders (Banasikowska, 2009; Bogucki, 2005).

Both the government of Poland and the European Union should be engaged in the development of e-administration in Poland. Any activities of these bodies should support particular public authorities carrying out e-administration tasks.

In Poland many sectorial and cross-sector projects aimed at implementing e-services have been launched. Such projects include: Electronic Platform for Electronic Services (ePUAP), Electronic Platform for Public Administration Services (ePUAP2), Public Administration ICT Network (STAP), electronic income statements of companies (e-statements 1 and e-statements 2), national registers (PESEL2), Central Vehicle and Driver Register (CEPiK), Subject Electronic Platform MS, Informative portal for notaries, solicitors, debt collectors and attorneys, Integrated System for State Budget Management of ERP class, a platform made available to entrepreneurs of services and digital resources of medical registers, electronic platform for gathering analyses and making digital resources about medical events available, a platform for communication with MSP and persons from social support area, Integrated Labor Market and Social Security System, Labor Supply and Demand Forecast System, e-Taxes, Icon, Cadastre System, National Official Register of the Territorial Division of the Country, Georeference Database of Topographic Structures, Public Statistics Information System, Consolidation and Centralization of Customs and Tax Systems, Central Business Activity Informatization (Banasikowska, 2009; Izdebski and Kulesza, 2004).

\section{Methods}

In this article the results of the studies on the functioning of e-administration in municipal offices of the Silesian Province as evaluated by disabled people are presented. The Province of Silesia is the second largest voivodeship in Poland in terms of population, and, at the same time, it has the largest number of towns of all the provinces in Poland (Wolniak and Skotnicka-Zasadzień, 2012).

Towns to be included in the studies were chosen by the stratified sampling method, whereas disabled persons in particular towns were randomly selected. In the first stage, 33 from among 71 towns in the Silesian Province were chosen. 
Next, random selection was applied to choose handicapped people who use the services of particular municipal offices. Survey studies were conducted in 2014. They resulted in obtaining 2,846 correctly completed questionnaires. Table 3 presents the detailed characteristics of the respondents participating in the studies.

Table 3: Characteristics of the respondents in the studies

\begin{tabular}{|c|c|c|c|}
\hline \multicolumn{2}{|c|}{ Specification } & \multirow{2}{*}{$\begin{array}{l}\text { Number of peo- } \\
\text { ple surveyed }\end{array}$} & \multirow{2}{*}{$\begin{array}{l}\text { Percentage of } \\
\text { respondents }\end{array}$} \\
\hline Division criterion & Range & & \\
\hline \multirow{2}{*}{ Sex } & Woman & 1,421 & $50 \%$ \\
\hline & Man & 1,425 & $50 \%$ \\
\hline \multirow{4}{*}{ Education } & Basic & 570 & $20 \%$ \\
\hline & Secondary & 1,591 & $56 \%$ \\
\hline & Higher & 651 & $23 \%$ \\
\hline & No answer & 34 & $1 \%$ \\
\hline \multirow{4}{*}{ Degree of disability } & Considerable & 400 & $14 \%$ \\
\hline & Moderate & 1,057 & $37 \%$ \\
\hline & Average & 1,384 & $49 \%$ \\
\hline & No answer & 5 & - \\
\hline \multirow{6}{*}{ Type of disability } & Sensory impairment & 644 & $23 \%$ \\
\hline & Intellectual impairment & 182 & $6 \%$ \\
\hline & Social functioning impairment & 399 & $14 \%$ \\
\hline & Communication impairment & 444 & $16 \%$ \\
\hline & Motor impairment & 1,153 & $40 \%$ \\
\hline & No answer & 24 & $1 \%$ \\
\hline \multirow{5}{*}{ Age } & Below 20 years of age & 225 & $8 \%$ \\
\hline & $20-29$ years & 763 & $27 \%$ \\
\hline & $30-39$ years & 758 & $27 \%$ \\
\hline & $40-49$ years & 641 & $22 \%$ \\
\hline & 50 years and more & 459 & $21 \%$ \\
\hline
\end{tabular}

Source: Authors' own study

First, the methods used most frequently by the disabled people for contacting with the public institutions were determined. Methods of client's communication with the office fall into two categories - traditional and electronic ones. Traditional methods include a traditional visit and taking care of official business directly at the office, sending traditional letters by post and telephone conversations with clerks. Electronic communication methods primarily consist of the latest solutions, i.e., full e-administration systems; besides, they also include communication via electronic mail or instant messengers.

Particular methods correspond to variables (variables were evaluated on a scale from 1 to 7 , where 1 corresponds to 'very seldom' and 7 - 'very often'):

- K1 - personal visit in an office;

- K2 - e-mail; 
- K3 - instant messengers;

- K4 - telephone call;

- K5 - letters, and

- K6 - e-administration systems.

In the case of using e-office services, the following variables were taken into consideration in the studies (variables were evaluated on a scale from 1 to 7 , where 1 corresponds to 'not important' and 7 - 'very important'):

- Zu1 - promptness of settling a matter;

- Zu2 - possibility of settling a matter without leaving home;

- Zu3 - office is open 24 hours a day;

- Zu4 - easier access to services for the disabled;

- Zu5 - safety;

- Zu6 - no queues;

- Zu7 - improved communication with the office, and

- Zu8 - reduced costs of using the office.

The following variables regarding the client's satisfaction with e-administration have also been taken into account in the research process (variables were evaluated on a scale from 1 to 7 , where 1 corresponds to 'I definitely do not agree', and 7 - 'I definitely agree'):

- J1 - promptness of provision of e-services;

- J2 - readability of the e-administration website;

- J3 - safety of service provision;

- J4 - easiness of finding e-office links on the website;

- J5 - comprehensible support regarding the use of e-office;

- J6 - the e-office website is user-friendly;

- J7 - promptness of services provided by the e-office;

- J8 - matters in the e-office are settled on the first attempt;

- J9 - use of e-office is safe;

- J10 - employees are willing to provide information on how to use e-office;

- J11 - employees provide without delay information on problems with the functioning of the e-office;

- J12 - employees promptly respond to e-mails;

- J13 - employees are willing to help clients;

- J14 - e-office keeps the client informed of their matter processing;

- J15 - employees are polite and friendly towards clients who have problems with e-office functioning;

- J16 - employees help the client if he/she has made a mistake related to the use of e-office;

- J17 - there are no problems to log in on the website, and

- J18 - the website functions under various browsers. 
The research had the following goals: (a) defining the scope of e-administration use by the disabled; (b) identifying the advantages of using e-administration from the point of view of a handicapped person, and (c) analyzing disabled persons' satisfaction with the functioning of e-administration in municipal offices of the Silesian Province.

Before beginning the studies the following hypothesis was formulated:

H1. More frequent use of electronic tools for communication with the office leads to increased satisfaction of the handicapped client with the functioning of e-administration.

\section{Results}

Figure 1 presents the tools used by the disabled people for communication with municipal offices. Evaluation was carried out using a scale from 1 signifying 'very seldom' to 7 'very often'. As indicated by the studies conducted, traditional methods are still prevalent - number one is a traditional personal visit at the office - score 5.24; the second place - a telephone call -4.34 . The majority of the surveyed disabled people do not use electronic tools when they have to take care of a matter at the office; instead they physically arrive at the office or call if they have any questions or problems. Among traditional methods only letters have become less important - currently they are used very seldom -2.97 .

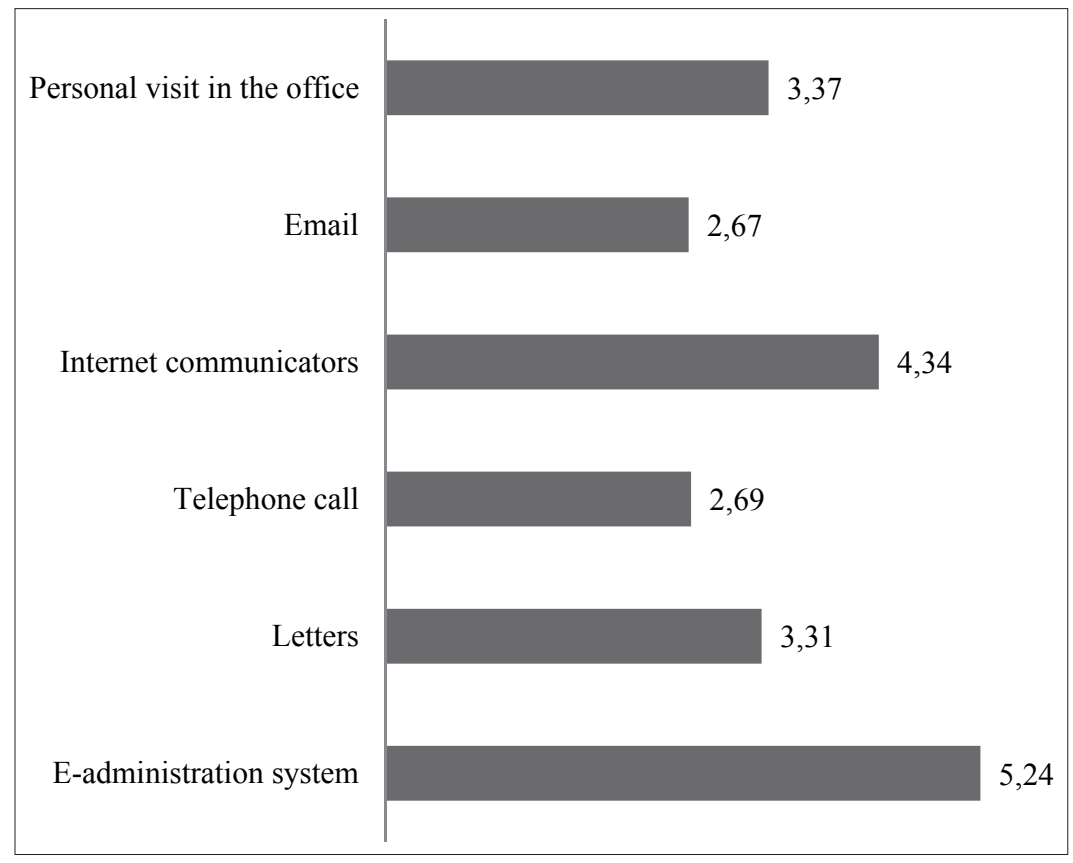

Figure 1: Methods of communication with the office used by the surveyed disabled people

Source: Authors' own study 
Among electronic communication methods, e-administration systems and e-mails are used only on an average level (3.27 for e-administration systems and 3.31 for e-mails respectively). The least frequently used electronic communication tools are instant messenger applications -2.69 .

The second investigated issue was to find out which were the biggest advantages of using the e-office in the opinion of the surveyed handicapped. The results have been given in Figure 2. The surveyed disabled decided that the lack of queues was the major benefit (score 5.83 on the seven-grade scale). Other very important advantages included: easier access to services for the disabled 5.65, and possibility of settling a matter without leaving home -5.45 .

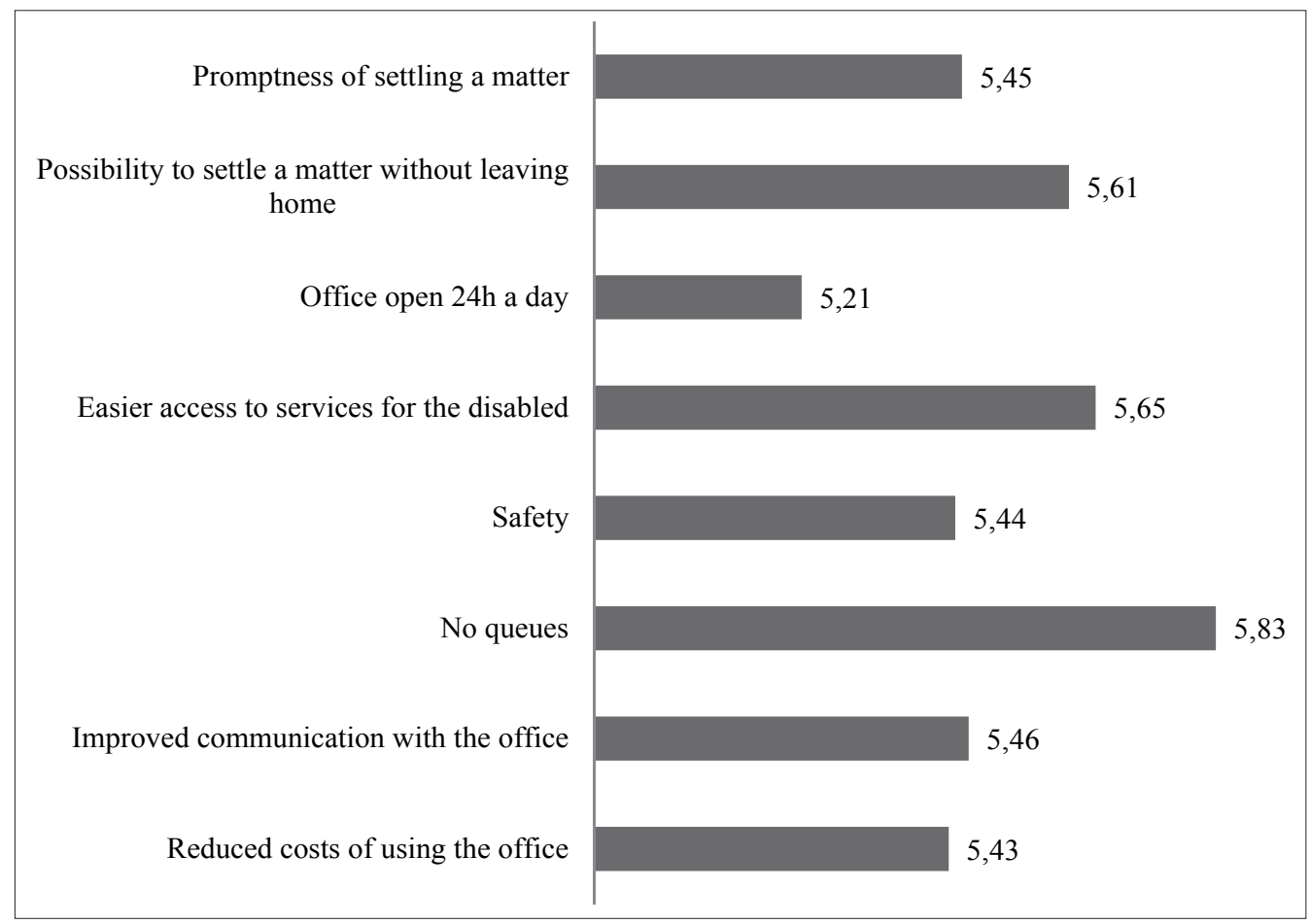

Figure 2: Benefits of using an e-office

Source: Authors' own study

The results for the advantages are high, which means that the disabled people perceive real benefits from using electronic means of communication with the office.

The last stage of the conducted studies was analyzing the client's satisfaction with e-administration in the municipal office in 33 investigated towns. For this purpose, 18 variables were defined, which have been discussed in the previous chapter. The results of evaluation for particular variables have been presented in Figure 3. The conducted research indicates that the best assessed areas of e-administration are:

- functioning of the office's website under various browsers (score 4.89);

- providing a service in a safe way (4.76); 
- polite and friendly attitude of employees towards clients who have problems with e-office functioning (4.77);

- safety of using the e-office (4.75); and

- employees help the client when they have made a mistake when using the e-office (4.75).

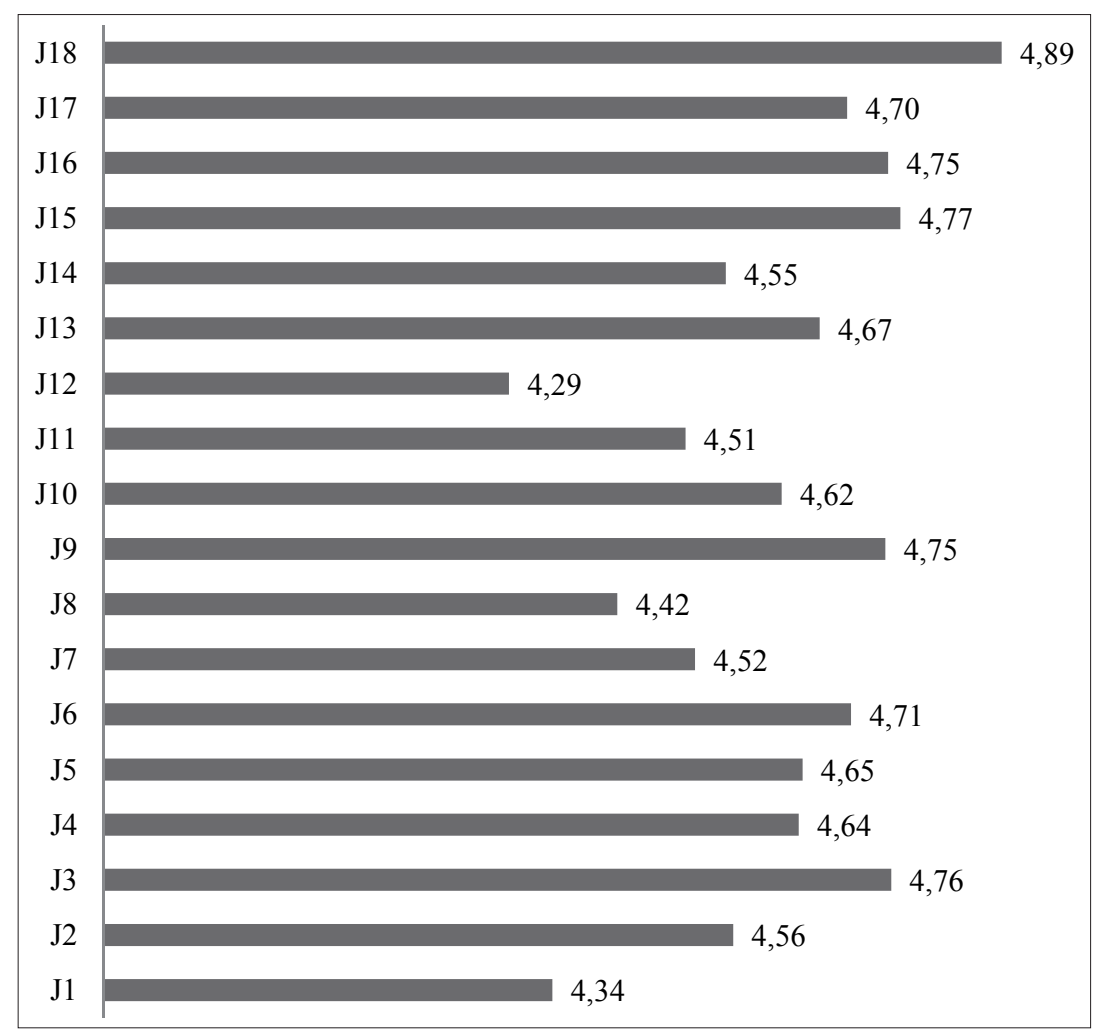

Figure 3: Evaluation of clients' satisfaction with e-administration in a municipal office

Source: Authors' own study

The lowest evaluated issues among the examined variables included:

- prompt reaction of employees to emails (4.29);

- prompt provision of an e-service (3.34); and

- settling matters practically on the first attempt (4.42).

Table 4 contains data concerning satisfaction with e-administration, divided into particular types of disability analyzed in the monograph. This variable only slightly differentiates the examined issues. ANNOVA Kruskal-Wallis test (Stanisz, 2007; Frankfort-Nachmias, Nachmias and DeWaard, 2014) has revealed the existence of statistically significant dependencies only in the case of two variables: J6 and J10, and only in the case of the lowest assumed level of significance $\alpha=0.05$. Satisfaction with the functioning of e-administration in municipal offices was rated the best by persons 
suffering from communication impairment (score 4.71), and the worst - by people with intellectual impairment (4.48). The differences are statistically important for the following variables:

- the variable regarding the user-friendliness of the website (variable J6) was given a score of 4.92 by persons with communication impairment, whereas people suffering from intellectual impairment rated it 4.54;

- the variable regarding the issue of employees' willingness to provide information on the use of the e-office (variable J10) was assessed at the level of 4.73 by persons with communication impairment, whereas people with intellectual impairment gave it a score of 4.3.

Table 4: Client's satisfaction with e-administration according to the type of disability

\begin{tabular}{cccccc}
\hline Variables & $\begin{array}{c}\text { Sensory } \\
\text { impairment } \\
(\mathrm{N}=644)\end{array}$ & $\begin{array}{c}\text { Intellectual } \\
\text { impairment } \\
(\mathrm{N}=182)\end{array}$ & $\begin{array}{c}\text { Social functioning } \\
\text { impairment } \\
(\mathrm{N}=399)\end{array}$ & $\begin{array}{c}\text { Communication } \\
\text { impairment } \\
(\mathrm{N}=444)\end{array}$ & $\begin{array}{c}\text { Motor } \\
\text { impairment } \\
(\mathrm{N}=1153)\end{array}$ \\
\hline J1 & 4.36 & 4.06 & 4.40 & 4.36 & 4.35 \\
\hline J2 & 4.67 & 4.41 & 4.53 & 4.62 & 4.53 \\
\hline J3 & 4.75 & 4.63 & 4.81 & 4.85 & 4.73 \\
\hline J4 & 4.72 & 4.43 & 4.53 & 4.73 & 4.65 \\
\hline J5 & 4.70 & 4.42 & 4.62 & 4.76 & 4.62 \\
\hline J6 & 4.79 & 4.54 & 4.69 & 4.92 & 4.61 \\
\hline J7 & 4.56 & 4.36 & 4.50 & 4.59 & 4.52 \\
\hline J8 & 4.47 & 4.41 & 4.39 & 4.55 & 4.37 \\
J9 & 4.83 & 4.66 & 4.75 & 4.79 & 4.70 \\
\hline J10 & 4.60 & 4.30 & 4.58 & 4.73 & 4.68 \\
\hline J11 & 4.47 & 4.30 & 4.51 & 4.58 & 4.53 \\
\hline J12 & 4.36 & 4.36 & 4.22 & 4.40 & 4.24 \\
\hline J13 & 4.67 & 4.57 & 4.61 & 4.75 & 4.69 \\
\hline J14 & 4.59 & 4.52 & 4.59 & 4.65 & 4.50 \\
\hline J15 & 4.83 & 4.53 & 4.71 & 4.87 & 4.76 \\
\hline J16 & 4.78 & 4.69 & 4.68 & 4.87 & 4.74 \\
\hline J17 & 4.84 & 4.65 & 4.66 & 4.79 & 4.63 \\
\hline J18 & 5.03 & 4.83 & 4.82 & 4.99 & 4.82 \\
\hline Average & 4.67 & 4.48 & 4.59 & 4.71 & 4.59 \\
\hline & & 5045 & & \\
\hline
\end{tabular}

Source: Authors' own study

\section{Discussion}

Many problems related to issues regarding disabled customer service in municipal offices, including in particular issues such as location of the office, its opening hours or architectural barriers making it difficult for the disabled to get around the office, can be solved by using e-administration tools. 
An analysis of results by means of U Mann-Whitney test (Corder and Foreman, 2014) revealed that for all the variables except the variable related to letters there are statistically significant differences in the use of particular communication tools between people preparing traditional and electronic form of communication. Understandably, persons preferring the electronic form use it much more frequently. For example, in the area of e-administration systems' use, people preferring the electronic form declare the use of e-administration on a level of 4.47, whereas the ones who prefer the traditional form - only 2.88. A similar situation is observed in the case of emails, the use of which was evaluated on a level of 4.24 by people preferring electronic communication, while persons preferring the traditional form of communication rated it as 2.9 .

The opposite situation is observed in the case of issues related to traditional means of communication. Then the difference between the preferences and actual use of a particular tool is smaller. The research shows that e-administration is not developed enough to be able to replace a traditional visit at the office or a telephone call. It is worth noting that even people who prefer the electronic form of communication, when asked about the use of particular communication tools, resort to a traditional visit at the office slightly more often (4.63) in comparison with e-administration systems (4.47). It is therefore clear that the barrier is not only on the side of persons using e-administration systems, but is also caused by the fact that these systems are not sufficiently developed and it is impossible to settle all matters electronically.

The analysis of correlations by means of ANOVA Kruskall-Wallis test (Fagerland and Sandvik, 2009) did not reveal statistically significant dependencies on any of the assumed levels of statistical significance between the degree of disability and the applied form of communication with the office. On the other hand, in the case of analysis in terms of disability degree, such a correlation exists for variables K2, K3, K5 and $\mathrm{K} 6$ on the level of statistical significance $\alpha=0.001$, whereas for the remaining variables it reaches $\alpha=0.05$.

An interesting fact is that before the research was conducted, it was assumed that the electronic form of communication would be more frequently used by persons with motor impairment - due to architectural barriers. However, the results showed a completely different picture of the situation. It turns out that issues related to social disorders encourage the surveyed disabled people to use new means of communication to a greater degree, enabling them to take care of official business without personal contact, which is important for people with this kind of disability. On the other hand, persons with motor impairment continue to stick to traditional communication by visiting the office in person.

Taking into consideration the results of studies in the previous chapter, the fact that safety issues are rated highly should be considered a positive thing, because safety-related issues are very important for e-services; in many cases a threat in this area is one of the major causes responsible for slow development of this form of communication. 
On the other hand, the main drawback is the promptness of e-administration. Issues related to e-services' functioning in terms of procedures or a possibility to settle matters on the first attempt are not always the responsibility of the office, but an alarming thing is that promptness of responding to emails was rated so poorly. This might also be a reason why email communication is not widely applied by clients. Clients prefer to call because then they receive an answer straight away, whereas in the case of email they have to wait longer, which is perceived as less convenient. Such reasoning is confirmed by the results of V-Crammer correlation between the use of emails as means of communication (variable K2) and evaluation of the promptness of clerks replying to emails (variable J12). This correlation is statistically significant on the level of $\alpha=0.001$ and reaches 0.28 . This means that if somebody thinks that clerks promptly respond to emails, he or she uses this form of communication more often, whereas in the event they believe this reaction is too slow, they use it less frequently.

In the end, it is also worth looking at some interesting results of Spearman's correlation between client's satisfaction and methods used to communicate with the office (Table 4) and advantages of using the e-office (Table 5). The collected data indicates that between the majority of variables there are positive correlations, statistically significant at the level of $\alpha=0.001$.

In the case of e-administration advantages, this indicates that if a disabled person using e-administration is satisfied with the level of service, he or she also positively perceives the benefits of using e-administration. On the other hand, in the event somebody encounters problems with the functioning of e-administration, they evaluate the benefits of its use much worse, which seems a natural thing.

Particularly interesting seems the analysis of Table 6. It indicates that the client's satisfaction with e-administration is positively correlated with variables K2, K3, K4 and $\mathrm{K} 6$ - i.e., the variables regarding the frequency of using e-administration. This indicates that the more often a particular person uses public e-services, the better he or she rates them. In general, e-services are evaluated worst by people who use it on a seldom basis. It seems that this is a positive conclusion, proving that the system of e-administration functions quite well, and problems result mainly from psychological barriers, the lack of computer skills (above a correlation between the level of computer literacy and satisfaction with using public e-administration has been proved) and similar factors. On the other hand, if somebody starts using the new electronic tools of communication with the office more frequently, they assess them as positive. 
Table 5: Spearman's correlation between client's satisfaction with e-administration and methods used for communication with the office

\begin{tabular}{|c|c|c|c|c|c|c|}
\hline & K1 & K2 & K3 & K4 & K5 & K6 \\
\hline J1 & -0.01 & 0.29 & 0.16 & 0.07 & 0.03 & 0.40 \\
\hline J2 & 0.06 & 0.23 & 0.14 & 0.15 & 0.04 & 0.35 \\
\hline J3 & 0.06 & 0.23 & 0.08 & 0.09 & -0.03 & 0.36 \\
\hline J4 & -0.01 & 0.22 & 0.12 & 0.14 & 0.01 & 0.31 \\
\hline J5 & 0.01 & 0.25 & 0.15 & 0.14 & 0.04 & 0.35 \\
\hline J6 & 0.05 & 0.25 & 0.16 & 0.15 & 0.06 & 0.35 \\
\hline $\mathrm{J} 7$ & 0.01 & 0.24 & 0.15 & 0.09 & 0.01 & 0.37 \\
\hline J8 & 0.00 & 0.25 & 0.17 & 0.10 & 0.03 & 0.37 \\
\hline J9 & 0.01 & 0.23 & 0.08 & 0.10 & 0.00 & 0.33 \\
\hline J10 & -0.01 & 0.22 & 0.11 & 0.12 & 0.00 & 0.31 \\
\hline J11 & 0.01 & 0.25 & 0.17 & 0.12 & 0.03 & 0.36 \\
\hline J12 & -0.04 & 0.28 & 0.19 & 0.08 & 0.12 & 0.31 \\
\hline $\mathrm{J} 13$ & 0.03 & 0.22 & 0.11 & 0.13 & 0.02 & 0.32 \\
\hline J14 & 0.00 & 0.26 & 0.15 & 0.13 & 0.04 & 0.35 \\
\hline J15 & 0.06 & 0.22 & 0.09 & 0.14 & 0.00 & 0.31 \\
\hline J16 & 0.05 & 0.24 & 0.13 & 0.16 & 0.01 & 0.31 \\
\hline J17 & 0.04 & 0.23 & 0.13 & 0.14 & 0.01 & 0.34 \\
\hline J18 & 0.05 & 0.22 & 0.07 & 0.09 & -0.02 & 0.32 \\
\hline
\end{tabular}

Source: Authors' own study

The results of studies conducted confirm hypothesis H1. More frequent use of electronic tools for communication with the office leads to increased satisfaction of the disabled client with the functioning of e-administration.

Table 6: Spearman's correlation between client's satisfaction with e-administration and benefits of using the e-office

\begin{tabular}{lllllllll}
\hline & Zu1 & Zu2 & Zu3 & Zu4 & Zu5 & Zu6 & Zu7 & Zu8 \\
\hline J1 & 0.28 & 0.23 & 0.28 & 0.27 & 0.29 & 0.23 & 0.29 & 0.25 \\
J2 & 0.32 & 0.27 & 0.27 & 0.30 & 0.26 & 0.30 & 0.30 & 0.21 \\
J3 & 0.34 & 0.33 & 0.31 & 0.35 & 0.34 & 0.34 & 0.34 & 0.26 \\
J4 & 0.28 & 0.26 & 0.26 & 0.29 & 0.25 & 0.26 & 0.29 & 0.24 \\
J5 & 0.27 & 0.25 & 0.27 & 0.29 & 0.26 & 0.30 & 0.31 & 0.21 \\
J6 & 0.28 & 0.25 & 0.26 & 0.29 & 0.25 & 0.27 & 0.29 & 0.23 \\
J7 & 0.26 & 0.23 & 0.27 & 0.28 & 0.28 & 0.24 & 0.31 & 0.22 \\
J8 & 0.22 & 0.23 & 0.25 & 0.29 & 0.28 & 0.24 & 0.31 & 0.23 \\
J9 & 0.29 & 0.28 & 0.31 & 0.31 & 0.31 & 0.30 & 0.33 & 0.25 \\
J10 & 0.24 & 0.27 & 0.27 & 0.31 & 0.29 & 0.27 & 0.30 & 0.25 \\
J11 & 0.21 & 0.23 & 0.25 & 0.30 & 0.28 & 0.25 & 0.30 & 0.24 \\
J12 & 0.22 & 0.14 & 0.17 & 0.22 & 0.24 & 0.18 & 0.24 & 0.22 \\
J13 & 0.25 & 0.26 & 0.28 & 0.30 & 0.24 & 0.28 & 0.29 & 0.20 \\
J14 & 0.24 & 0.22 & 0.24 & 0.29 & 0.25 & 0.25 & 0.29 & 0.20 \\
J15 & 0.29 & 0.27 & 0.23 & 0.30 & 0.24 & 0.31 & 0.31 & 0.23 \\
J16 & 0.28 & 0.25 & 0.23 & 0.30 & 0.23 & 0.31 & 0.30 & 0.22 \\
J17 & 0.27 & 0.26 & 0.23 & 0.28 & 0.25 & 0.30 & 0.31 & 0.25 \\
J18 & 0.30 & 0.26 & 0.25 & 0.26 & 0.22 & 0.30 & 0.28 & 0.21 \\
\hline
\end{tabular}

Source: Authors' own study 


\section{Conclusion}

The studies presented in this publication allowed for proving the formulated research hypothesis regarding a correlation between more frequent use of electronic tools of communication with the office and the client's satisfaction with the functioning of e-administration. The investigations conducted allowed for confirming the above hypothesis.

The research also indicates that disabled clients' satisfaction with the functioning of e-administration is relatively high. Another positive fact is that satisfaction is growing in the group of people who frequently deal with e-administration and can serve e-office systems. Such a situation bodes well for the future and suggests that as the disabled become better acquainted with e-administration systems, their use of these systems will also increase.

\section{References:}

1. Banasikowska, J. and Banasikowski, P., 'Poziom rozwoju e-Government w Polsce', in Pańkowska, M., Porębska-Miąc, T. and Sroka H. (eds.), Systemy Wspomagania Organizacji, Katowice: Wydaw. Uniwersytetu Ekonomicznego w Katowicach, 2008.

2. Banasikowska, J. and Stanek, S., Analiza przydatności systemu elektronicznej komunikacji administracji publicznej SEKAP do realizacji e-usług w województwie ślaskim, Katowice: Wydawnictwo Uniwersytetu Ekonomicznego w Katowicach, 2012.

3. Banasikowska, J., 'Systemy elektronicznego dostępu do administracji', in Pańkowska, M., Porębska-Miąc, T. and Sroka, H. (eds.), Systemy Wspomagania Organizacji, Katowice: Wydaw. Uniwersytetu Ekonomicznego w Katowicach, 2009.

4. Bartnicka, J. and Mleczko, K., 'Doskonalenie e-usług publicznych z uwzględnieniem potrzeb osób o różnych typach niepełnosprawności', 2013, Roczniki Kolegium Analiz Ekonomicznych, vol. 29, pp. 23-35.

5. Batta, M., Sethi, A. and Kaur, R., 'E-Governance in E-Administration', 2012, International Journal of Computing and Business Research, pp. 13-18.

6. Betchoo, N.K., 'An Insight into the Practice of e-Government. A Road Map for Contemporary Public Administration', 2016a, International Journal of Trend in Research and Development, vol. 3, no. 2, pp. 526-530.

7. Betchoo, N.K., Public Sector Management. A Millennial Insight, Ventus Publishing, 2016b.

8. Bickenbach, J.E., Cieza, A., Rauch, A. and Stucki, G. (eds.), ICF Core Sets Manual for Clinical Practice, Göttingen: Hogrefe Publishing GmbH, 2012.

9. Bogucki, D., 'e-Government w Unii Europejskiej', 2005, E-administracja, vol. 1, pp. 15-28.

10. Brinkerhoff, J. and Brinkerhoff, D., 'Government-nonprofit Relations in Comparative Perspective: Evolution, Themes and New Directions', 2002, Public Administration and Development. Special Issue: Government-Nonprofit Relations in Comparative Perspective, vol. 22, no. 1, pp. 3-18.

11. Brodnicki, K., Kubiszewska, K. and Tymoszuk, E., 'E-administracja w ujęciu jakościowym i finansowym', 2012, Zarzadzanie i Finanse, vol. 3, no. 3, pp. 55-64.

12. Corder, G.W. and Foreman, D.I., Nonparametric Statistics: A Step-by-Step Approach, Hoboken, NJ: John Wiley and Sons, 2014. 
13. Dečman, M., Stare, J. and Klun, M., 'E-government and Cost-effectiveness: e-taxation in Slovenia', 2010, Transylvanian Review of Administrative Sciences, vol. 31E, pp. 48-57.

14. Fagerland, M.W. and Sandvik, L., 'The Wilcoxon-Mann-Whitney Test under Scrutiny', 2009, Statistics in Medicine, vol. 28, no. 10, pp. 1487-1497.

15. Frankfort-Nachmias, C., Nachmias, D. and DeWaard, J., Research Methods in the Social Sciences, New York: Worth Publishers, 2014.

16. Garbat, M., 'Społeczne i ekonomiczne modele niepełnosprawności', 2013, Kwartalnik Niepełnosprawność i Rehabilitacja, vol. 1, pp. 9-14.

17. García, B., Gómez, A., Conde, R., Hernández, Y. and Valero, M.A., 'Breaking the Web Barriers of the e-Administration Using an Accessible Digital Certificate Based on a Cryptographic Token', 2015, Advances in Software Engineering, vol. 3, pp. 1-11.

18. Holliday, I. and Yep, R., 'E-government in China', 2005, Public Administration and Development, vol. 25, no. 3, pp. 239-249.

19. Izdebski, H. and Kulesza, M., Administracja publiczna - zagadnienia ogólne, Warszawa: Liber, 2004.

20. Kasprzyk, B., 'Aspekty funkcjonowania e-administracji dla jakości życia obywateli, Nierówności Społeczne a Wzrost Gospodarczy', Uniwersytet Rzeszowski, Rzeszów, 2011.

21. Kažemikaitiene, E. and Bilevičiene, T., 'Problems of Involvement of Disabled Persons in e.government', 2008, Technological and Economic Development, vol. 14, no. 2, pp. 184-196.

22. Liu, S.M. and Yuan, Q., 'The Evolution of Information and Communication Technology in Public Administration', 2015, Public Administration and Development, vol. 35, no. 2, pp. 140-151.

23. Ndou, V., 'E - government for Developing Countries: Opportunities and Challenges', 2004, The Electronic Journal of Information Systems in Developing Countries, vol. 18, no. 1, pp. 1-24.

24. Omariba Bosire, Z. and Okebiro Omari, J., 'Characterising E-participation Levels in E-governance', 2015, International Journal of Scientific Research and Innovative Technology, vol. 2, no. 1, pp. 157-166.

25. Pradela, A., 'Determinants of the Employment of People with Disabilities in Poland', International Multidisciplinary Scientific Conference on Social Sciences and Arts SGEM2014, Conference Proceedings, September 1-9, 2014, book 2, vol. 1, pp. 105-112.

26. Pradela, A. and Żabińska, I., Uwarunkowania zatrudnienia osób niepełnosprawnych w województwie śląskim, Gliwice: Pracownia Komputerowa Jacka Skalmierskiego, 2015.

27. Ruso, J., Krsmanovic, M., Trajkovic, A. and Rakicevic, Z., 'Quality Management in Public e-Administration', 2013, International Journal of Management Science and Engineering, vol. 7, no. 10, pp. 550-554.

28. Salvatore, S.C., 'Government Employment and Pay: The Global and Regional Evidence', 1998, Public Administration and Development, vol. 18, no. 5, pp. 457-478.

29. Stanisz, A., Przystępny kurs statystyki z zastosowaniem STATISTICA PL. Analizy wielowymiarowe, Kraków: StatSoft, 2007.

30. Strejcek, G. and Theil, M., 'Technology Push, Legislation Pull? E-government in the European Union', 2002, Decision Support Systems, vol. 34, pp. 305-313.

31. Szewczyk, A., Społeczeństwo informacyjne - problemy rozwoju, Warszawa: Wydawnictwo Difin, 2007. 
32. Teicher, J., Hughes, O. and Dow, N., 'E-government: A New Route to Public Sector Quality', 2002, Managing Service Quality: An International Journal, vol. 12, no. 6, pp. 384393.

33. Tỏza, I., 'Virtual Reality and Public Administration', 2013, Transylvanian Review of Administrative Sciences, vol. 38E, pp. 202-212.

34. Act of August 27, 1997 on professional and social rehabilitation and employment of disabled people Dziennik Ustaw no. 123. Pos. 776 with later changes in 2002.

35. Vrabie, C., 'Education-A Key Concept for E-Administration', 2015, Procedia-Social and Behavioral Sciences, vol. 186, pp. 371-375.

36. Wiliński, M., 'Modelowe strategie pomocy osobom z ograniczeniami sprawności: medykalizacja - usprawnianie - włączanie', in Brzezińska, A.I., Kaczan, R. and Smoczyńska, K. (eds.), Diagnoza potrzeb i modele pomocy dla osób z ograniczeniami sprawności, Warszawa: Wydawnictwo Naukowe Scholar, 2010.

37. Wolniak, R. and Skotnicka-Zasadzień, B., 'Ocena czynników jakości usług w administracji samorządowej', 2010, Marketing i Rynek, vol. 6, pp. 32-36.

38. Wolniak, R. and Skotnicka-Zasadzien,, B., 'The Concept Study of Servqual Method's Gap', 2012, Quality and Quantity, vol. 46, no. 4, pp. 1239-1247. 